\title{
Differentiate or die: reconstructing market(place) economies
}

\author{
Alfonso Morales $^{1}$ \\ Accepted: 5 April 2020 / Published online: 13 May 2020 \\ (c) Springer Nature B.V. 2020
}

I see a young Latina holding an expensive $35 \mathrm{~mm}$ camera, acquired by income earned by her and her mom who disrupted the household patriarchy to make their own street vending business. During the Spanish Flu, farmers markets and public markets attracted people until illness finally disrupted their operations.

A robust society is like a healthy ecology, constantly being disrupted by differentiations that alter habitual interactions, cause reactions, and create new interactions in new niches. COVID-19 is the reality of that principle in action-mutation is endemic and permits fitness to host environments. Ultimately these mutations complement an existing spirit of a time or slowly replaces it. For instance, the financial crash of 2008 squeezed out the remaining inefficiencies of late capitalism in the U.S. in favor of a spirit of hyper-individualism focused on employment in service and technology, the products of both being largely focused on the individual. However, farmers markets, swap meets, and the like were continuing to foster a distinct spirit, starting with the farmer or hobbyist practicing their craft, seeking effective use of materials, replenishing soils, and conserving the taste of a region, while attending to new immigrants, people's purposes, and new perceptions of place.

The spirit of marketplaces is one of ambition and effectiveness in contrast to efficiency and complexity. Modern society fosters efficiency, that produces a mechanistically complex society, which reduces people to economic moments in production processes. Marketplaces foster complete communities, making social tempos and spaces appropriate to the many roles people play and to their interactions with farming, family life, or other activities intersecting in those spaces. People purchase farm and craft products, but

This article is part of the Topical Collection: Agriculture, Food \& Covid-19.

$\triangle$ Alfonso Morales

Morales1@wisc.edu

1 Vilas Distinguished Achievement Professor, University of Wisconsin-Madison, Madison, USA at the market they produce and partake of experiences that make society. Visitors see each other, learn from demonstrations, and perhaps share their skills with each other. Visitors also observe vendors and can ask about how the product came to be. Today, government co-produces safety and fosters social and economic health in these spaces by working with market managers to produce guidelines for farmers markets. Even store-front retail, historically born in markets, seeks new opportunities in them today.

The reemergence of farmers markets in the 1960s and 1970s embodied bioregionalism. Today, bioregional concerns prompt the integration of economic, political, and regulatory efforts on behalf of sustainability. Likewise, COVID may hasten socio-economic reorganization at different geopolitical scales. We will see. Meanwhile, farmers markets in Wisconsin, my home state, are deemed essential services, and Dane County has 27 farmers markets in the summer, two are less than a mile from my house and not a neighborhood in Madison is more than two miles from a market. Likewise, around the country, food trucks, urban and rural farmers, and artisans will continue to find retail opportunities at markets. More important, markets will continue to produce cosmopolitan people, varying in why they visit, what they do, and how they see and learn from each other at marketplaces.

So, instead of being killed by COVID or late capitalism, marketplaces around the world, in industrialized countries or otherwise, produce resilience and responsiveness to catastrophic events, fostering opportunities for women marginalized in households or immigrants marginalized at their destinations or local businesses and farmers. In the U.S. some 9000 farmers markets make for place-based resilience. Many states have declared farmers markets as essential services and those are adapting swiftly by experimenting with guidance from government, as well as technologies, physical and online, to support safe transactions. The public remains engaged and hopeful, not only for products, but in support of values, places to hold forth with others, and foster community.

We know trade in goods and services has united the planet for thousands of years. We should not reject international 
trade, we need to embrace local trade. We need not reject an interest in efficiency, we need to support the spirit of the local, fostering across society the spirit of a place and the knowledge of the niches, economic, social, political, and ecological, that populate that place. We need to act on behalf of differentiation, not for the sake of difference, but in the spirit of cooperation, creativity, and the co-production of resilient places, robust societies, and interactions that support our common humanity.

Publisher's Note Springer Nature remains neutral with regard to jurisdictional claims in published maps and institutional affiliations.

Alfonso Morales, $\mathrm{PhD}$ (Northwestern), is Vilas Distinguished Achievement Professor of Planning and Landscape Architecture at the University of Wisconsin at Madison. His affiliations include the School of
Medicine and Public Health, the Institute of Research on Poverty, and Chican@/Latin@Studies. He co-founded farm2facts.org which is used by farmers market managers in the U.S. and Canada. He is originally from rural New Mexico with roots in family farming, there and in West Texas. He is a researcher, advocate, and practitioner/consultant on food systems and public markets, inclusive of entrepreneurial, organizational, and regulatory aspects of these activities. He has been invited to speak on these topics internationally. His nationally recognized and policy-relevant program of research on street vendors and marketplaces has described the organization and consequences of marketplace and vending processes historically and in different places around the world. This work has shaped policy in New York City, Kansas City, Denver, and elsewhere. His research examines the intersection of these markets with various modalities of identity, including gender and race. He has also contributed to our understanding of business organizations, public health, and social theory. He has six books on these topics. His 80 other publications are found in Spanish and English and have appeared in the top journals of five different disciplinary associations, including Aztlan, the American Journal of Sociology, Economic Development Quarterly, the Journal of the American Planning Association, and the Law and Society Review. He has extensive experience with students in community-based outreach and research. 